\title{
Numerical Investigation of Solar Enhanced Passive Air Cooling System for Concentration Photovoltaic Module Heat Dissipation
}

\author{
Zheng Zou, Hengxiang Gong, Jingshu Wang, and Shilie Xie
}

\begin{abstract}
The major issue related to the passive air cooling technology for high concentration photovoltaic (HCPV) module is that their heat dissipation efficiencies highly rely on the ambient temperature and wind speed. It may not provide enough cooling for solar cells causing the malfunction of HCPV module under the worst case scenario, i.e., high ambient temperature and no wind condition. In this study, a novel passive air cooling device, named as Solar Enhanced Passive Air Cooling System (SEPACS), was proposed. To verify its performance advantage over conventional aluminum plate heat sink, a three dimensional model was developed in the CFD software. Numerical comparative analysis shows that the SEPACS can keep cell temperature under $75^{\circ} \mathrm{C}$ when the concentration ratio reaches to $\mathbf{7 0 0}$, while solar cells cooled by conventional aluminum plate heat sink would be overheated at same concentration ratio.
\end{abstract}

Index Terms-HCPV, passive air cooling, solar chimney.

\section{INTRODUCTION}

At present, more than $60 \%$ of the power supply in China is from fossil fuel power generators, which are believed to be one of major sources of air pollution. Therefore, the need for reusable energy resources has become ever more important. Consequently, the government has taken active steps to encourage the development of renewable energy resources such as the wind energy, biomass energy, and especially solar energy. High concentration photovoltaic (HCPV) is a technology utilizing a large area optical device to concentrate sunlight onto a solar cell with much smaller size. A typical HCPV system comprises multiple concentration devices (normally Fresnel lens), an array of high-efficiency solar cells, and a tracking system [1]. The HCPVs differ from traditional photovoltaic panels primarily in their use of a light-concentration module to enhance the optic electric transition efficiency [2]. Although HCPV may be the most promising solution to reduce the price of PV electricity, it still has some unsolved technical problems, which restrict its large-scale application. How to provide an efficient cooling for solar cells is one of them. Without a highly efficient cooling solution, under such a high-concentrated solar radiation intensity, the temperature of solar cells rise rapidly, and thus jeopardizing the power output or even causing irreversibly damage to solar cells due to overheating [3], [4].

Manuscript received October 9, 2015; revised March 3, 2016.

The authors are with the Chongqing University of Technology, Chongqing, $400054 \quad$ China (e-mail: z.zou@cqut.edu.cn, gonghx@cqut.edu.cn, donotwang@163.com, $897938181 @$ qq.com).
Hence, it is critical to design a high-efficient cooling device for HCPV heat dissipation.

Generally, there are various cooling methods for the HCPV system in the literature, such as the passive air cooling [5]-[9], active air cooling [10], water cooling [11], [12], directly-immersed cooling [13], heat pipe cooling [14], micro-channel cooling [15], [16], jet impingement cooling [17], and Peltier effect cooling [18], [19]. In consideration of the reliability of cooling device, the passive air cooling may be the most practical cooling solution for the HCPV system. At present, a typical passive air cooling system utilizes the effects of natural convection and radiation to dump waste heat for HCPV by sticking a metal plate heat sink (mostly aluminum) to the bottom of cell (or cells). To understand and enhance the heat dissipation efficiency of passive air cooling system, several studies has been reported in the literature. Natarajan et al. [6] developed a two dimensional thermal model to predict the temperature of a concentrated PV module (concentration ratio X 10) with and without passive cooling arrangements. The simulation results show that by adding additional fins, the cooling performance of aluminum plate heat sink can be increased. Do et al. proposed a general correlation of aluminum heat sink with fins for HCPV heat dissipation by conducting a series of experiments [7]. They found that the optimal fin spacing strongly depends on the temperature difference and the inclination angle of heat sink. By running extensive experiments on a HCPV module under high concentration ratio (820 times), Nishioka et al. proposed that with a new type thermal radiation coating, the temperature of solar cells can be further reduced (approximately $10^{\circ} \mathrm{C}$ ), and accordingly the open-circuit voltage of the HCPV module was $0.5 \mathrm{~V}$ higher than that of the module without this coating [8]. Wang et al. developed a three-dimensional model for a HCPV module under 476 times of solar concentration, results reveal that the cell temperature within the HCPV module reduces as the wind speed increases [9].

The major problem related to the present passive air cooling systems for HCPV is that their heat dissipation efficiencies highly rely on the ambient temperature and wind speed. When the ambient temperature rises sharply, the aluminum plate heat sink would not work properly under no wind condition and consequently expose solar cells to high temperature. Unfortunately, this worst case scenario happens a lot in the summer noon. Based on the fact that the high ambient temperature always comes with high solar radiation intensity, this paper proposes a novel cooling device, Solar Enhanced Passive Air Cooling System (SEPACS), which can 
make use of solar energy to generate self-stimulated airflow to properly dissipate the waste heat of solar cells for coupled HCPV module even under the worst case scenario (i.e., high ambient temperature plus no wind condition). As shown in Fig. 1, it consists of three major parts, i.e., the aluminum pipes, solar collector and chimney. Solar cells within the HCPV module are directly placed upon the aluminum pipe, which works as the heat sink. The pipe outlet connects with the inlet of solar collector. The upper side of solar collector is made of aluminum and is painted black to maximally absorb solar radiation, while other sides are made of insulated fiber-reinforced phenolic foam plates. The airflow leaving the pipes would be further heated inside solar collector until it reaches at the bottom of chimney, which is used to enhance the chimney effect. With this structural arrangement, air can be automatically sucked into the channels of aluminum pipes and take away the waste heat of solar cells. In order to quantify the advantages of SEPACS over the conventional aluminum plate heat sink, a three-dimensional model was developed for the proposed SEPACS in this study and comparative analysis was conducted in the following sections.

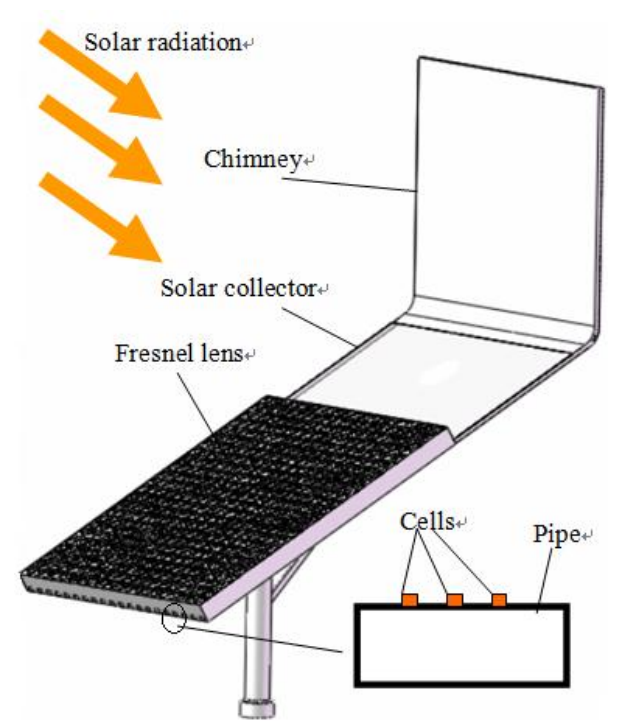

Fig. 1. The main components of a SEPACS.

\section{Modeling}

As a test case, five identical HCPV modules (composed of 39 high-efficiency mono silicon solar cells in each) cooled by a single SEPACS were numerically investigated in this study by using the Fluent CFD software [20]. To focus the discussion on the thermodynamic issue, we assumed that the absorption at the Fresnel lens and electrical output contributes to $25 \%$ of the solar energy received by cells. That means the waste heat needed to be dumped accounts for $75 \%$ of total heat received from the solar irradiance. The main objective of this numerical modeling is to predict the cell temperature in the HCPV module under peak solar illumination, which happens in the hottest noon in summer. Hence, in these simulations, the nominal ambient temperature, the elevation angle of modules, solar radiation intensity were considered as constants with values of $30^{\circ} \mathrm{C}, 60$ degrees, and $800 \mathrm{~W} / \mathrm{m}^{2}$ respectively to meet the real ambient condition in the north

\section{Hemisphere.}

Computational domain: Fig. 2 presents the computational domain used in the following simulations. The principal dimensions (length $L \times$ height $H \times$ width $W$ ) of the aluminum pipes are $1400 \mathrm{~mm} \times 100 \mathrm{~mm} \times 200 \mathrm{~mm}$. The solar collector has the height of $200 \mathrm{~mm}$, length of $3000 \mathrm{~mm}$, and width of $2000 \mathrm{~mm}$ respectively while the chimney has the same dimensions.

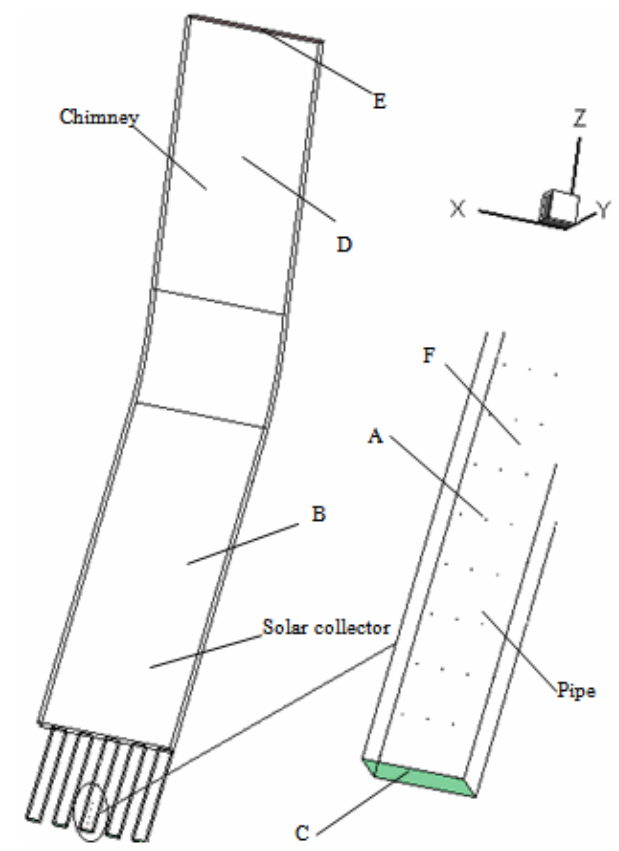

Fig. 2. Computation domain and boundary settings of 3-D model.

Boundary condition: The upper side of solar collector was represented by the wall boundary condition with constant heat flux of $800 \mathrm{~W} / \mathrm{m}^{2}$. Considering the different concentration ratio (400 to 700), photoelectric transformation efficiency and absorption at Fresnel lens (25\% in total), the imposed uniform intensity on the top cell surface varies from 240000 to $420000 \mathrm{~W} / \mathrm{m}^{2}$. The pipe inlets were defined as the pressure inlet boundary conditions while the chimney outlet was described as the pressure outlet boundary condition. It should be noted that the relative pressure in both boundaries was set as $0 \mathrm{~Pa}$. That is because the static pressures of same height inside and outside of the SEPACS should be the same as the ambience. Major boundary settings are listed in Table I.

Governing equations: The Semi-Implicit Method for Pressure-Linked Equations (SIMPLE) algorithm was used in simulations to calculate pressure and velocity fields which were then used to solve the energy equation. The standard k- $\varepsilon$ equation was employed here to describe the turbulence condition in SEPACS. The solution of this 3-D model is based on solving a series governing equations including continuity equation, momentum equation, energy equation, and $k-\varepsilon$ equations. The general term of governing equations can be written as:

$$
\nabla \cdot(\rho \vec{u} \Phi-\Gamma \nabla \Phi)=S_{\Phi}
$$

where, the expressions for $S_{\phi}, \phi$ and $\Gamma$ are given in Table II. 
TABLE I: MAJOR BOUNDARY SETTINGS

\begin{tabular}{ccc}
\hline position & Type & Value \\
\hline A & Wall & $\begin{array}{c}240000 \text { to } 420000 \mathrm{~W} / \mathrm{m}^{2}, \\
\text { wall thickness of } 1 \mathrm{~mm}, \\
\text { activated shell conduction } \\
800 \mathrm{~W} / \mathrm{m}^{2}, \text { wall thickness } \\
\text { of } 1 \mathrm{~mm}, \text { activated shell } \\
\text { conduction }\end{array}$ \\
B & Wall & $T_{o}=303.15 \mathrm{~K}, P_{i}=0 \mathrm{~Pa}$ \\
C & Pressure inlet & Wall wall without heat \\
D & Pressure outlet & $P_{o}=0$ Pa \\
E & wall & $\begin{array}{c}\text { No-slip wall with thickness } \\
\text { of } 1 \mathrm{~mm}, \text { activated shell } \\
\text { conduction }\end{array}$ \\
& &
\end{tabular}

TABLE II: EXPRESSIONS FOR $S_{\phi}, \phi$ AND $\Gamma$ IN GOVERNING EQUATIONS

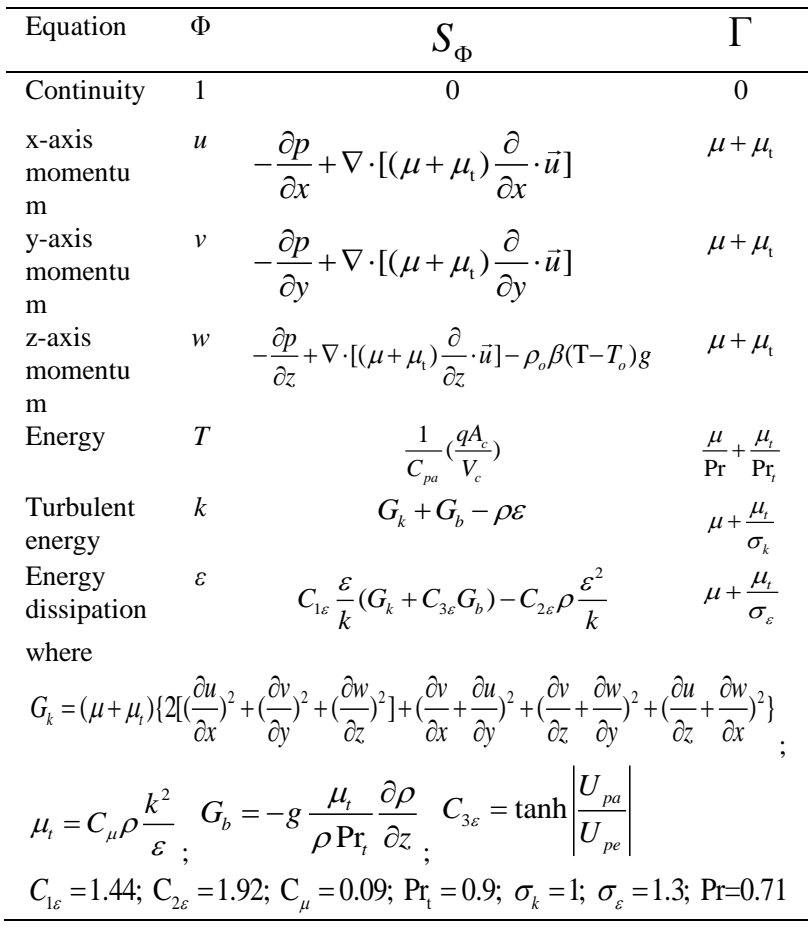

Note that for buoyancy calculations, a source term representing buoyancy effect is added to $\mathrm{z}$-axis momentum equation as follows

$$
S_{b}=-\rho_{o} \beta\left(\mathrm{T}-T_{o}\right) g
$$

where, the $\beta$ is the thermal expansive coefficient and was pre-defined according to selected ambient temperature. The convergence criterion is that the residual of energy equation drops to the order of $10^{-6}$ while the residuals of others fall below $10^{-4}$. Both unstructured tetrahedral and hexahedral meshes were used. Grid-independence has been tested by running each test case at different mesh sizes (i.e., the number of cells varying from 2000,000 to 4000,000 ) until consistent results were reached (less than $1 \%$ error).

\section{MODEL VALIDATION}

Without considering the dissipation duty for solar cells, the flow characteristics in the SEPACS are similar to those in the solar chimney for room ventilation. Therefore, our numerical model presented in this paper can be validated by the field experimental data from a solar chimney [21].

Detailed comparison between the numerical simulation results and the experimental data was carried out. The computation parameters were set according to the following experimental data: The dimensions of cavity are $1.965 \mathrm{~m} \times$ $0.765 \mathrm{~m} \times 0.1 \mathrm{~m}$ (Height $\times$ Width $\times$ Depth $)$, the heat flux on the heated area are $220 \mathrm{~W} / \mathrm{m}^{2}$, ambient temperature is $25^{\circ} \mathrm{C}$. The temperature differences between air inside and ambience obtained from the numerical simulation and experiment are shown in Table III. Table III indicates a satisfactory agreement can be found between the simulation results and the experimental data. It means our presented numerical model is qualified to investigate the heat dissipation performance of SEPACS.

TABLE III: COMPARISON BETWEEN THE EXPERIMENTAL RESULTS AND NUMERICAL RESULTS

\begin{tabular}{ccc}
\hline $\begin{array}{c}\text { Position of probe point } \\
\text { divided by total length } \\
{[-]}\end{array}$ & $\begin{array}{c}\text { Predicted temperature } \\
\text { difference between air } \\
\text { inside and ambience }\end{array}$ & Experiment \\
\hline 0.12 & $42.2 \mathrm{~K}$ & $43 \mathrm{~K}$ \\
0.41 & $50.8 \mathrm{~K}$ & $52 \mathrm{~K}$ \\
0.88 & $56.8 \mathrm{~K}$ & $57 \mathrm{~K}$ \\
\hline
\end{tabular}

\section{RESUlTS AND DISCUSSION}

In generally, the higher concentration ratio, the higher cell temperature would be. Normally, the mono silicon solar cell can work properly under $75^{\circ} \mathrm{C}(348.15 \mathrm{~K})$. High working temperature would negatively affect the photoelectric conversion efficiency of solar cells, resulting the misalignment of HCPV module. Hence, simulations were carried out to see whether the SEPACS can keep the cell temperature in the HCPV modules within the reasonable range at different concentration ratios. Fig. 3-Fig. 7 illustrate the temperature distributions of one of these five HCPV modules at three different concentration ratios, i.e., 400, 500, 600,650 , and 700 respectively. The results show that the maximum cell temperature always occurs to the three solar cells adjacent to the pipe outlet. An explanation for this observation is that the air current keeps be heated up by solar cells. When solar cells receive the heat from concentrated sunlight, it has a heat conduction with coupled aluminum pipe. As the thermal transfer medium, the pipe transfers large portion of heat from solar cells to the self-stimulated air current flowing within it by convection. Therefore, the airflow becomes warmer and warmer along its travel and gets harder and harder to take away the waste heat of the solar cells due to the decreasing temperature difference between airflow and solar cells. Besides, the simulation results also show that the values of self-simulated airflow velocity inside the pipe at different sunlight concentration ratios are almost the same (around $2.8 \mathrm{~m} / \mathrm{s}$ ). It reveals that the driving force of airflow mainly relies on the heat transfer inside the solar collector rather than the waste heat of solar cells. Fig. 3-Fig. 7 also show that the SEPACS can always keep the cell temperature under $310 \mathrm{~K}$ degrees Celsius (around $37^{\circ} \mathrm{C}$ ) even the concentrating ratio reaches 700 . Under such a low working temperature, the solar cells are capable to properly generate electricity without any threat from overheating. 


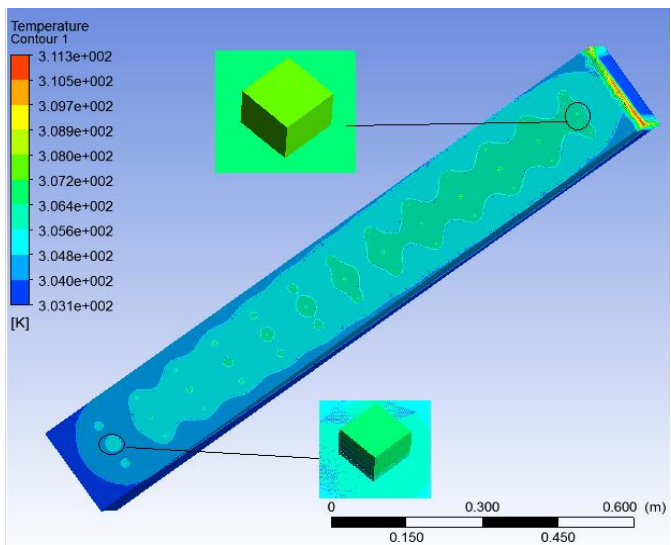

Fig. 3. The temperature distribution of cells cooled by SEPACS at the concentration ratio of 700 .

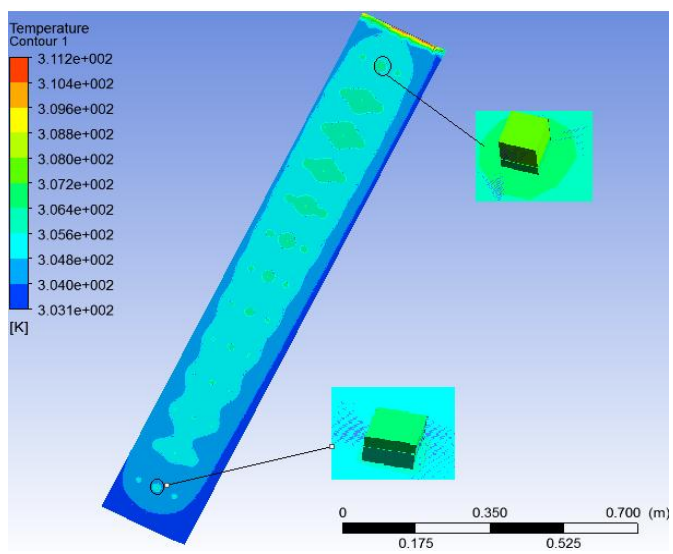

Fig. 4. The temperature distribution of cells cooled by SEPACS at the concentration ratio of 650

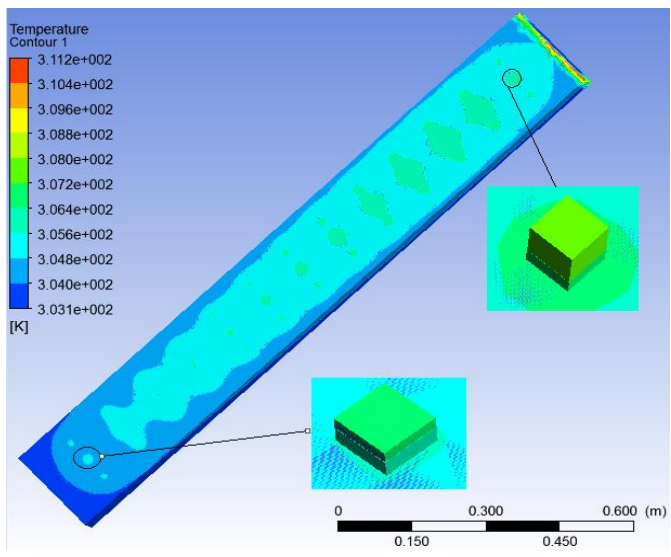

Fig. 5. The temperature distribution of cells cooled by SEPACS at the concentration ratio of 600 .

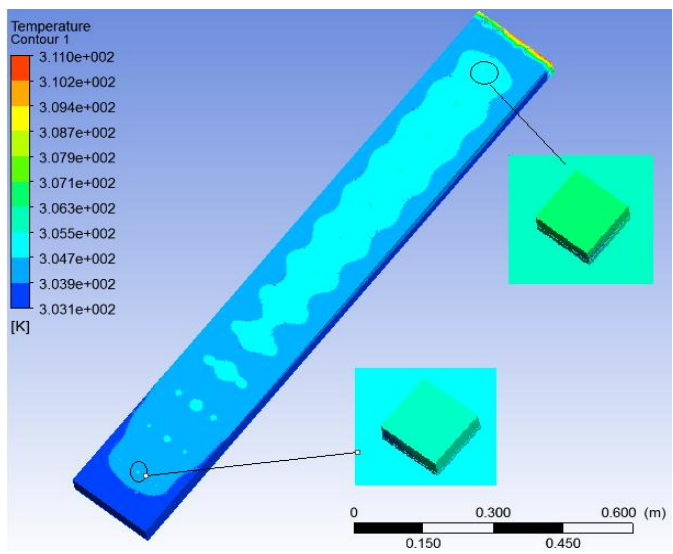

Fig. 6. The temperature distribution of cells cooled by SEPACS at the concentration ratio of 500 .

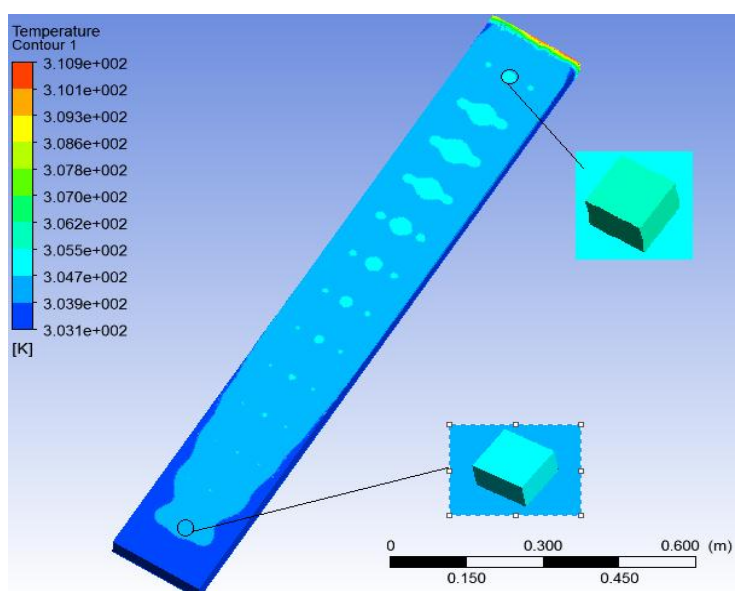

Fig. 7. The temperature distribution of cells cooled by SEPACS at the concentration ratio of 400 .

For comparison, we also developed another 3-D model for previous mentioned HCPV module equipped with a conventional aluminum plate heat sink with the similar geometry $(1400 \mathrm{~mm}$ in length X $1 \mathrm{~mm}$ in thickness X $200 \mathrm{~mm}$ in width). In order to simulate the worst case scenario, the environmental air velocity was set to $0.2 \mathrm{~m} / \mathrm{s}$ in this model. Fig. 8-Fig. 12 shows the cell temperature distributions of this module at the concentration ratios of 400, 500, 600, 650 and 700 respectively. It reveals that the solar cells cooled by the aluminum plate heat sink increases greatly with the increasing concentration ratio.

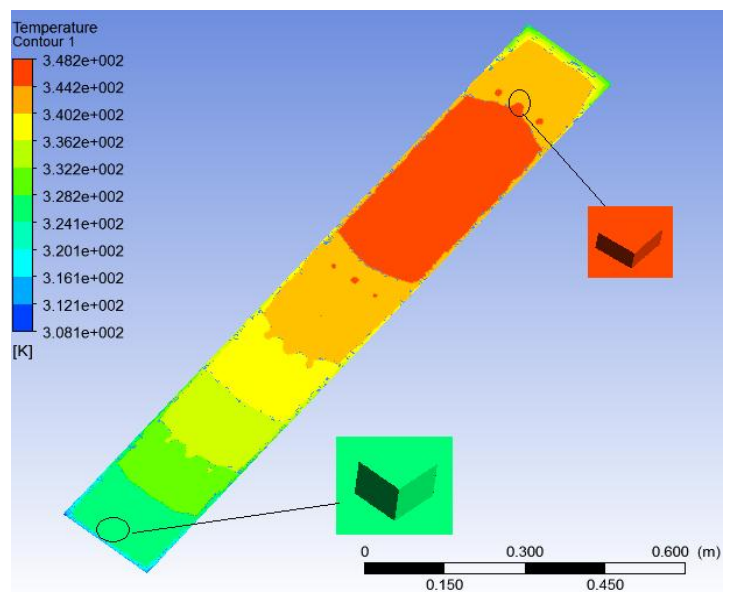

Fig. 8. The temperature distribution of cells cooled by SEPACS at the concentration ratio of 700 .

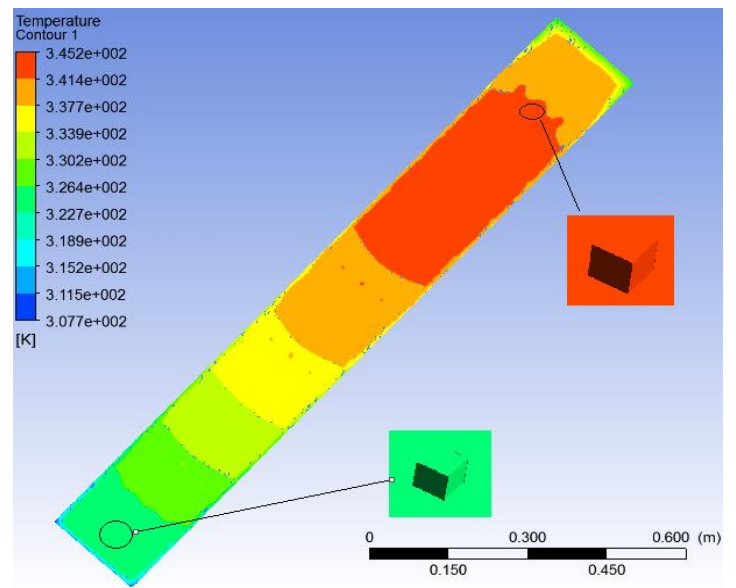

Fig. 9. The temperature distribution of cells cooled by SEPACS at the concentration ratio of 700 . 
It should be noted that in Fig. 8, the maximum temperature of cells already exceeds $348.15 \mathrm{~K}\left(75^{\circ} \mathrm{C}\right)$, which means under such a working condition, this HCPV module hardly can have a proper power output and it could be burnt down in a short period. By putting our focus on the maximum cell temperature in each test case mentioned above, Fig. 13 can be created. It indicates that under same working circumstance and heat duty, with similar geometrical parameters, the novel SEPACS always has a better cooling performance over the conventional aluminum plate heat sink.

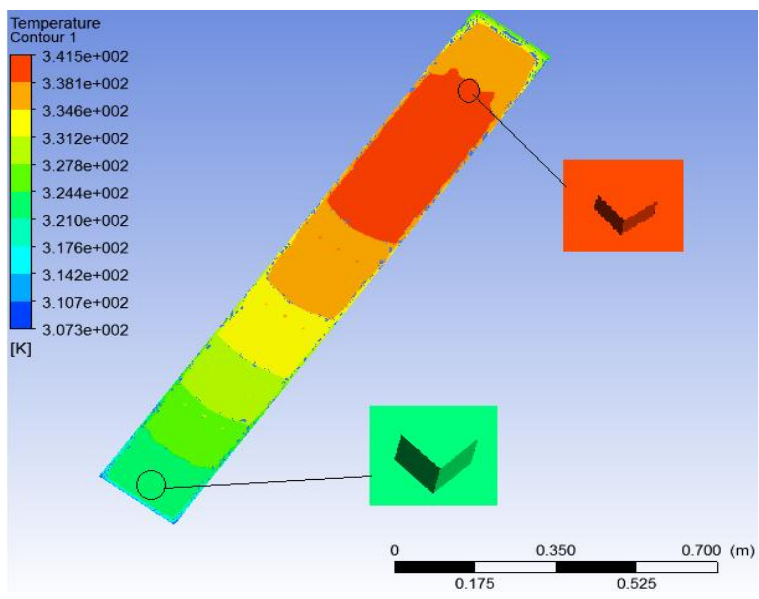

Fig. 10. The temperature distribution of cells cooled by SEPACS at the concentration ratio of 650 .

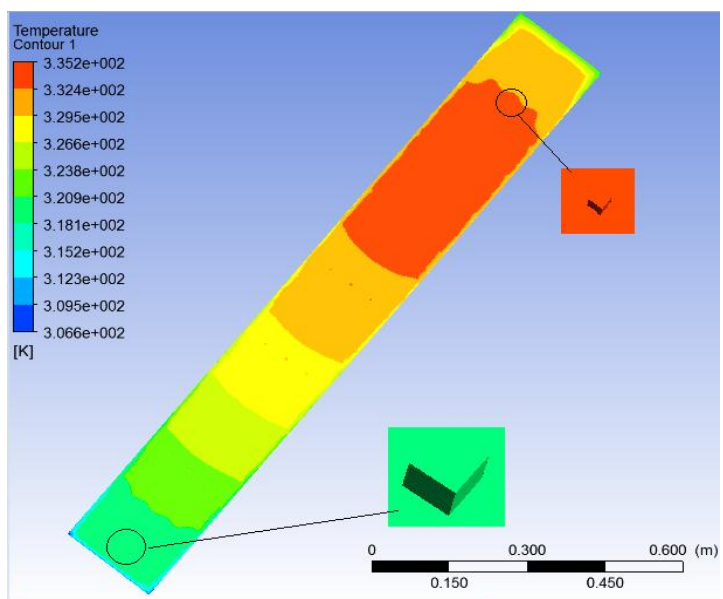

Fig. 11. The temperature distribution of cells cooled by SEPACS at the concentration ratio of 500 .

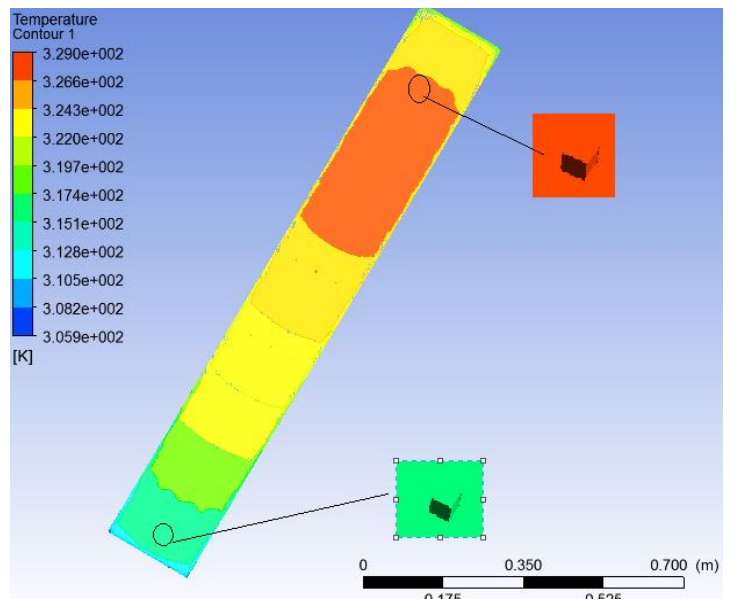

Fig. 12. The temperature distribution of cells cooled by SEPACS at the concentration ratio of 400

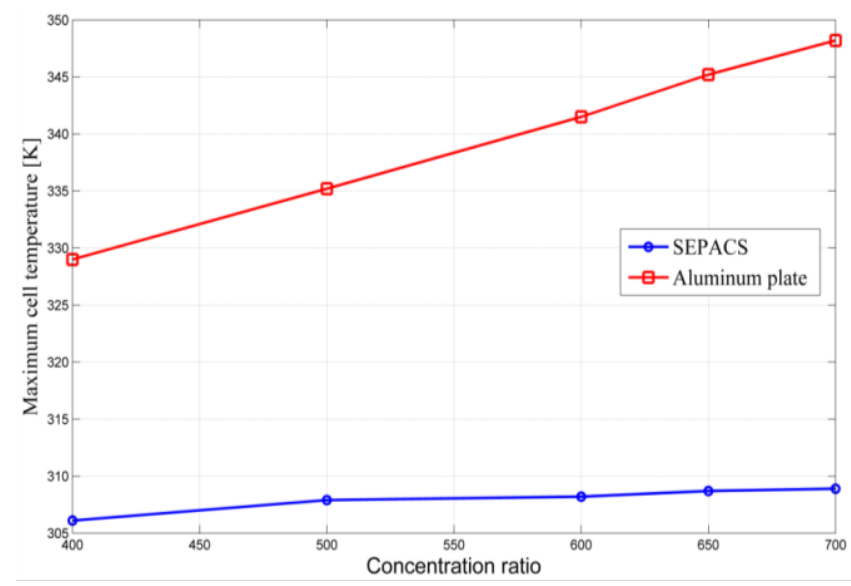

Fig. 13. The Maximum cell temperature at different concentration ratio.

\section{CONCLUSION}

In this study, we proposed a novel passive cooling solution for the HCPV h, i.e., Solar Enhanced Passive Air Cooling System (SEPACS). Unlike conventional passive cooling device, it can harness abundant solar irradiance to automatically stimulate an airflow conducting enhanced convection heat transfer between air and solar cells to be cooled. As a result, it can properly work even under high ambient temperature and no wind condition. To quantify its performance advantage over conventional aluminum plate heat sink, a 3-D numerical model was developed for both SEPACS and aluminum plate heat sink. Numerical simulation results shows that our proposed novel cooling system is capable to keep cell temperature under $75^{\circ} \mathrm{C}$ even the concentration ratio reaches 700 , while the conventional aluminum plate heat sink with similar geometry could not provide enough cooling for coupled solar cells. According to these simulation results, we believe the SEPACS may be a highly efficient passive cooling solution for HCPV, and it may have promising prospect in the HCPV industry.

\section{REFERENCES}

[1] C. T. Kuo, H. Y. Shin, H. F. Hong, C. H. Wu, C. D. Lee, and I. T. Lung, "Development of the high concentration III-V photovoltaic system at INER, Taiwan," Renewable Energy, vol. 34, pp. 1931-1933, 2009.

[2] A. W. Bett, B. Burger, F. Dimroth, G. Siefer, and H. Lerchenmüller, "High-concentration PV using III-V solar cells," in Proc. 4th World Conference on Photovoltaic Energy Conversion, 2002, pp. 615-620.

[3] D. J. Mbewe, H. C. Card, and D. C. Card, "A model of silicon solar cells for concentrator photovoltaic and photovoltaic thermal system design," Solar Energy, vol. 35, pp. 247-258, 1985.

[4] V. L. Dalal and A. R. Moore, "Design considerations for high-intensity solar cells," Journal of Applied Physics, vol. 48, pp. 1244-1251, 1977.

[5] K. Araki, H. Uozumi, and M. Yamaguchi, "A simple passive cooling structure and its heat analysis for $500 \mathrm{x}$ concentrator PV module," in Proc. 29th IEEE Photovoltaic Specialists Conference, 2002, pp. 568-1571.

[6] S. K. Natarajan, T. K. Mallick, M. Katz, and S. Weingaertner, "Numerical investigations of solar cell temperature for photovoltaic concentrator system with and without passive cooling arrangements," International Journal of Thermal Sciences, vol. 50, pp. 2514-2521, 2011.

[7] K. H. Do, T. H. Kim, Y. S. Han, B. Choi, and M. B. Kim, "General correlation of a natural convective heat sink with plate-fins for high concentrating photovoltaic module cooling," Solar Energy, vol. 86, pp. 2725-2734, 2012

[8] K. Nishioka, Y. Ota, K. Tamura, and K. Araki, "Heat reduction of concentrator photovoltaic module using high radiation coating," Surface and Coatings Technology, vol. 215, pp. 472-475, 2013. 
[9] Y. N. Wang, T. T. Lin, J. C. Leong, Y. T. Hsu, C. P. Yeh, P. H. Lee, and C. H. Tsai, "Numerical investigation of high-concentration photovoltaic module heat dissipation," Renewable Energy, vol. 50, pp. 20-26, 2013.

[10] F. Al-Amri and T. K. Mallick, "Alleviating operating temperature of concentration solar cell by air active cooling and surface radiation," Applied Thermal Engineering, vol. 59, pp. 348-354, 2013.

[11] Jr. F. C. Kern and M. C. Russell, "Optimization of photovoltaic/thermal collector heat pump system," in Proc. the International Solar Energy Society Meeting, 1979, pp. 1870-1874.

[12] M. I. Hussain and G. H. Lee, "Experimental and numerical studies of a U-shaped solar energy collector to track the maximum HCPV/T system output by varying the flow rate," Renewable Energy, vol. 76, pp. 735-742.

[13] Y. Sun, Y. P. Wang, L. Zhu, B. Q. Yin, H. J. Xiang, and Q. W. Huang, "Direct liquid-immersion cooling of concentrator silicon solar cells in a linear concentrating photovoltaic receiver," Energy, vol. 65, pp. 263-271.

[14] A. Akbarzadeh and T. Wadowski, "Heat pipe-based cooling systems for photovoltaic cells under concentrated solar radiation," Applied Thermal Engineering, vol. 1, pp. 81-87, 1996.

[15] A. Royne and C. J. Dey, "Design of a jet impingement cooling device for densely paced PV cells under high concentration," Solar Energy, vol. 81, pp. 1014-1024, 2007.

[16] J. Barrau, A. Perona, A. Dollet, and J. Rosell, "Outdoor test of a hybrid jet impingement/micro-channel cooling device for densely paced concentrated photovoltaic cells," Solar Energy, vol. 107, pp. 113-121, 2014.

[17] K. S. Reddy, S. Lokeswaran, P. Agarwal, and T. K. Mallick, "Numerical investigation of Micro-channel based active module cooling for solar HCPV system," Energy Procedia, vol. 54, pp. 400-416, 2014.

[18] H. Najafi and K. A. Woodbury, "Optimization of a cooling system based on Peltier effect for photovoltaic cells," Solar Energy, vol. 91, pp. 152-160.

[19] N. Ari and A. Kribus, "Impact of the Peltier effect on concentrating photovoltaic cells," Solar Energy Materials and Solar Cells, vol. 94 , pp. 2446-2450, 2010.

[20] ANSYS Fluent 13, Theory Guide, Fluent Inc., 2011.

[21] G. E. Lau, E. Sanvicente, G. H. Yeoh, V. Timchenko, M. Fossa, C. Ménézo, and S. Giroux-Julien, "Modelling of natural convection in vertical and tilted photovoltaic application," Energy and Buildings, vol, 55, pp. 810-822, 2012.

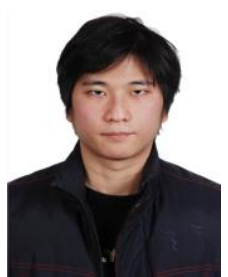

Zheng Zou was born in Chongqing, China, on May 4 1985. He received the Ph.D. degree in mechanic engineering from University of Queensland, Australia in 2014. He is currently a lecturer in the School of Mechanical Engineering, Chongqing University of Technology, China. His current research interests are solar thermal application and air cooling technology.

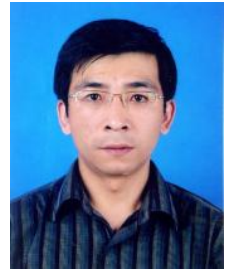

Hengxiang Gong was born in Lanzhou city, Gansu, China, on January 2, 1971. He received the Ph.D. degree in physics from Lanzhou University, China in 2002. He is currently a lecturer in the school of optoelectronic information, Chongqing University of Technology, China. His current research interests are photovoltaic power generation technology application in Southwest China.

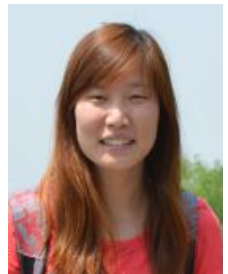

Jingshu Wang was born in Anhui, China, in 1988 She received the Ph.D. degree of precision instruments and machinery from the University of Science and Technology of China in 2013. From July 2013 to present, she worked at the Mechanical Engineering School of Chongqing University of Technology as a lecturer. Her present research focuses on the photovoltaic system and the system modeling.

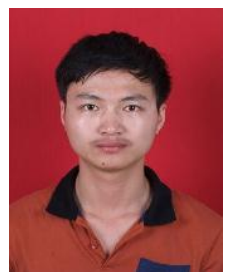

Shilie Xie was born in Jiang Xi, China, in 1992. He received the bachelor's degree in mechanical engineering from Nanchang Institute of Technology, China, in 2014.

$\mathrm{He}$ is currently studying at the School of Mechanical Engineering, Chongqing University of Technology as a postgraduate student. His present research interest is on the photovoltaic system and air cooling technology. 